\title{
Çevre İle İlgili Mitlerin Öğrenci Görüşlerine Göre İncelenmesi
}

\author{
D Havva Nur YEŞİL \\ Gazi Üniversitesi \\ yyesil.havva@gmail.com \\ Mehmet YILMAZ \\ Gazi Üniversitesi \\ myilmaz@gazi.edu.tr
}

Gönderilme Tarihi: 11/02/2021

Kabul Tarihi: 31/07/2021

Yayınlanma Tarihi: 31/07/2021

\begin{tabular}{|c|c|}
\hline Makale Bilgileri & ÖZET \\
\hline $\begin{array}{l}\text { Anahtar Kelimeler: } \\
\text { Biyoçeşitlilik, } \\
\text { Çevre eğitimi, } \\
\text { Çevresel mitler, } \\
\text { Doğa koruma }\end{array}$ & $\begin{array}{l}\text { İnsan populasyonunun büyümesi, yüzlerce türün neslinin tükenmesine ve } \\
\text { binlercesinin de yok olma tehlikesiyle karşı karşıya kalmasına sebep olmuştur. } \\
\text { Bu değişiklikler biyoceşitliliğin kaybını göstermektedir. Biyoçeşitliliğin } \\
\text { korunması için yapılan araştırmalarda yöresel olarak anlatılan efsanelerin, } \\
\text { hikayelerin ve mitlerin bölgenin fauna ve florasının korunmasında büyük etkisi } \\
\text { olduğu bildirilmektedir. Kaynağını halkın geçmişinden, kültüründen, hatta } \\
\text { yaşadığı coğrafi konumdan alan halk inanışları; bir halkın, en erken } \\
\text { dönemlerinden başla1yarak ortaya çıkan fikir şeklini, çevre ve doğa ile olan } \\
\text { geleneksel bağlarını göstermektedir. Bu araştırmanın amacı, ortaöğretim } \\
\text { öğrencilerinin çevresel ve ekolojik mitler doğrultusunda biyoçeşitliliğe bakış } \\
\text { açısının ne ölçüde değiştiğini çeşitli değişkenler açısından incelemektir. Yarı } \\
\text { yapılandırılmış görüşme formunun kullanıldığı bu araştırma, 2017-2018 eğitim } \\
\text { öğretim yılı güz döneminde dört farklı ildeki farklı okullardan, çeşitli } \\
\text { kademelerdeki ortaöğretim öğrencileri ile gerçekleştirilmiştir. Çalışma grubu } \\
\text { tüm lise çeşitlerinde öğrenim gören } 400 \text { öğrenciden oluşmaktadır. Uygulanan } \\
\text { yarı yapılandırılmış görüşme formunda dört farklı mit ve bu mitlere ait açık } \\
\text { uçlu sorular bulunmaktadır. Bu formlar dört yüz katılımcıya uygulanmıştır. } \\
\text { Yarı yapılandırılmış görüşme formunun değerlendirilmesi sonucu elde edilen } \\
\text { verilere göre ana temalar oluşturulmuştur. Verilen yanıtlar; inanç, çevre koruma } \\
\text { ve çevre bilinci, ekonomi ve turizm, kültürel, doğal denge ve biyolojik çeşitlilik, } \\
\text { realist yaklaşım olmak üzere altı kategoride toplanmıştır. Bunun yanı sıra } \\
\text { belirlenen görece farklı yorumlar ise diğer başlı̆g altında toplanmıştır. } \\
\text { Araştırma bulgularına göre, çevresel mitlerin doğayı korumada olumlu } \\
\text { etkilerinin olduğu, ekoturizmi geliştirdiği belirlenmiştir. Ancak araştırmaya } \\
\text { katılan öğrencilerin bir kısmı böyle mitler olmasa da çevrenin korunması } \\
\text { gerektiği şeklinde görüş bildirmişlerdir. }\end{array}$ \\
\hline
\end{tabular}

\footnotetext{
${ }^{1}$ Bu araştırma Prof. Dr. Mehmet YILMAZ danışmanlığında yürütülen Havva Nur YEŞiL'in 2019 yılında tamamladığı yüksek lisans tezinden üretilmiştir.

Yeşil, H. N., \& Yılmaz, M. (2021). Çevre ile ilgili mitlerin öğrenci görüşlerine göre incelenmesi. Gazi Eğitim Bilimleri Dergisi, 7(2), 138-154. https://dx.doi.org/10.30855/gjes.2021.07.02.002
}

Dergi Web Sayfası: http://dergipark.gov.tr/gebd 


\section{Examining of Environmental Myths According to Student Opinions}

\begin{tabular}{|c|c|}
\hline Article Info & ABSTRACT \\
\hline $\begin{array}{l}\text { Keywords: } \\
\text { Biodiversity, } \\
\text { Environmental } \\
\text { education, } \\
\text { Environmental } \\
\text { myths, } \\
\text { Protection of nature }\end{array}$ & $\begin{array}{l}\text { The increase in human population caused the extinction or dangerous depletion } \\
\text { of hundreds of many species. This indicates the decrease in biodiversity. The } \\
\text { biodiversity studies show that the local myths, legends or tales of the local } \\
\text { people have a significant effect on the protection of regional fauna and flora. The } \\
\text { myths which emerge from the very early past, culture and even the geography } \\
\text { of the people illustrate their opinions and their traditional ties with environment } \\
\text { and nature. The purpose of this study is the investigation of the amount of the } \\
\text { change of the opinions of the secondary education students towards the } \\
\text { biodiversity based upon ecological myths according to the different variables. } \\
\text { The study was carried out on secondary education students at various levels } \\
\text { studying in Sanliurfa, Antalya- Alanya, Kahramanmaras- Elbistan and Konya- } \\
\text { Doganhisar in } 2017-2018 \text { academic year by the use of constructed interview } \\
\text { forms. The study group consists of } 400 \text { students from all types of high schools. } \\
\text { The constructed interview form consisted of open-ended questions about the } \\
\text { four different myths. A main theme was formed according to the data obtained } \\
\text { from the constructed interview forms. The answers were collected under six } \\
\text { different categories as belief, environmental protection and awareness, culture, } \\
\text { economy and tourism, environmental balance and biological diversity and } \\
\text { realist approach. The opinions other these were collected under "others" } \\
\text { category. The result of the study revealed of the students stated that the } \\
\text { environmental myths are quite useful in environmental protection and think } \\
\text { that they promote the ecotourism. The students stated the opinion that the } \\
\text { environment is being protected anyhow without needing such myths. }\end{array}$ \\
\hline
\end{tabular}

\section{GİRIŞ}

Küresel ölçekte insan populasyonundaki artış, özellikle çevre üzerinde olumsuz etkilere neden olmuştur. Ailede başlaması beklenen çevre eğitiminin yetersizliği, bireyler tarafından doğaya verilen zararları normalleştirilmektedir. Bu durum öncelikle doğayı, dolayısı ile insan hayatını olumsuz yönde etkilemektedir. İnsanlar tüm canlılar gibi çevreleri ile etkileşim halindedirler. Ekoloji doğal olarak biyolojik birlikteliklerin korunması kadar, yerel kültürlere saygıyı da gerektirmektedir (Demir ve Çevirgen, 2006).

Yerkürede, yalnızca belirli coğrafyalarda var olan ve başka bir bölgede doğal olarak bulunmayan türlere endemik tür denir (Simon, Dickey, Hogan ve Reece, 2017). Endemik türlerin yayılış gösterdikleri alan farklılık göstermektedir. Endemik türlerin yayılış alanlarının sınırlı olması, türlerinin devamlılığı açısından tehlike unsuru oluşturabilmektedir. Türkiye, çok sayıda endemik türe ev sahipliği yapmaktadır. Bunda ortam şartlarındaki çeşitlilik de etkili olmuştur (Şenkul ve Kaya, 2017). Endemik türlerin soyunun tükenme tehlikesine girmesi küresel bir sorundur. Bu durum etik kavramını gündeme getirmektedir. 
Eğitimde etiğin önemi her geçen gün artmaktadır. Etiğin kelime anlamının ahlak ile de ilintili olması, öğrencilerin toplumsal konular üzerinde düşünmesini gerektirmektedir (Karakaya ve Arslan, 2016). Karakaya ve Arslan bu çalışmada öğrencilerde etik kavramının geliştirilmesi gerektiğini ifade etmişlerdir. Alanyazında yer alan bu çalışma etiğin mitlerle desteklenebileceğini göstermektedir.

Ekolojik dengenin bozulması beraberinde sürdürülebilir kalkınma kavramını da önemli hale getirmiştir. Sürdürülebilir kalkınma; bugünün ihtiyaçlarını karşılarken doğal kaynakları korumak ve gelecek nesillere iyi bir çevre aktarabilmek için yapılan etkinliklerdir (Collin, 2004). Sürdürülebilirlik kavramı ilk defa 1980 yılında yayımlanan Dünya Koruma Stratejisi (WCS-The World Conservation Strategy) ile kamuoyunun dikkatini çekmiştir. Biyosfere verdiğimiz hasar dikkate alındığında, ekologlar, alarm verici bir hızla türlerin nesillerinin tükenmeye doğru sürüklendiğine inanmaktadırlar. Günümüzdeki tür kaybı oranı, yüz bin yıl öncesindeki herhangi bir zamanla karşılaştırıldığında belki yüz kat daha fazladır. Bu durumun oluşmasında, habitatların tahrip edilmesi ve parçalara bölünmesi, ortama yabancı türlerin sokulması, aşırı tüketim ve küresel iklim değişiklikleri gibi birçok etmen vardır. Habitatların tahrip edilmesi; soy içi üreme ve devamında genetik sürüklenmeye neden olarak biyoçeşitliliği azaltmaktadır. Ortama sokulan yabancı türler istilacı tür haline gelerek komüniteye zarar verebilir. Komünitenin zarar görmesi bölgenin tür zenginliği ve nispi bolluğunu doğrudan veya dolaylı olarak etkileyecektir. Biyoçeşitliliğin korunması için in situ (yerinde, doğal) koruma ve ex situ (doğal habitatı dışında) koruma yöntemleri geliştirilmiştir (Selim, Selim ve Mutlu, 2015). Türkler kültürleri gereği doğaya saygı duymuş, hayvanları merkezine alan bir mitoloji oluşturmuşlardır. Hayvanlardan her alanda faydalanmış ve onlara kıymet atfetmişlerdir. Bu doğrultuda, doğaya ve hayvanlara zarar verenler cezalandırılmıştır (Gacar, 2020).

Konu ile ilgili alanyazın incelendiğinde, mitolojilerin türlerin korunmasında etkili olduğu görülmektedir. Örneğin Polat ve Topçu (2018), doğadaki canlılara zarar verilmemesi hususunda mitolojiden faydalanılabileceğini vurgulamışlardır. Aynı zamanda edebiyattan da yardım alınması gerektiği anlayışını benimsemişlerdir. Endonezya ve civarındaki çok sayıdaki adada "Nyi Pohaci Sanghyang Sri" olarak adlandırılan mitolojik tanrıçanın özellikle pirinç başta olmak üzere her türlü bitkinin yetişmesini kolaylaştırdığına inanılmaktadır. Bu tanrıçaya atfedilen hikâyeler, yöre halkının bitkileri ve onların yetiştiği ortamları korumalarına katkı sağlamaktadır (Holil, 2020). Karakaya, Atilla, Alakabak ve Yılmaz (2019) tarafindan yapılan araştırma sonucunda, endemik türlerin korunmasında ortaöğretim öğrencilerinin yaşanmışlıkları ve sahip oldukları etik değerlerin etkili olduğu belirlenmiştir. Karakaya ve Arslan (2016), hayvanların deneylerde kullanılmasına yönelik etik değerlerinin olaylara göre farklıllk gösterdiğini ifade etmişlerdir.

Kültür, çevrenin ve kritik ekosistemlerin korunmasında önemli bir rol oynar. Maru, Gebrekirstos ve Haile (2020), yerel inançların, kutsal yerlerin, kültürel uygulamaların ve geleneksel kuralların, çevreyi korumada ve sosyokültürel değerleri teşvik etmede önemli rol oynadığını ortaya koymuşlardır. Kutsal 
olarak kabul edilen bir ormanlık alandaki ağaç biyoçeşitliliğinin hemen yakınlardaki diğer ormanlık alanlardan çok yüksek olduğu ve daha iyi korunduğu; yerel inanç sistemlerinin ve sosyal tabuların, insanları kutsal alanlardaki ağaçları kesme, kuşları öldürme ve dikkatsizce doğaya zarar verme konusunda sınırlandırdığı bildirilmiştir. Toplumun sosyo-kültürel ve ahlaki öğretilerini etkileyen ögeler arasında düşünsel süreçlerin varlığı kabul edilen bir gerçektir. Deneysel ve zihinsel süreçleri barındıran biyoloji araştırmalarında ulaşılan neticelerin toplumun sosyal ve kültürel değerlerine etki etmesi ve onlarda kalıı izli değişiklikler meydana getirmesi söz konusudur.

Alanyazında yer alan çalışmaların yanı sıra Milli Eğitim Bakanlığı tarafından hazırlanan 2023 Eğitim Vizyonu Felsefesi de evrensel insanlık değerlerinin eğitim ile harmanlanması gerektiğine dayanmaktadır. Geleceğe doğru kurduğumuz köprüler olarak ifade edilen öğrencilerin hem akademik hem sosyal anlamda donatılması gerektiği ifade edilmektedir. Ayrıca 21. yy becerileri arasında da evrensel etik kavramlarına değinilmektedir (MEB, 2018, s.14). Bu çalışma, bu bağlamda 2023 vizyon felsefesini destekleyen verilere de yer vermektedir.

\section{Araştırmanın Amacı}

Çevre sorunlarının çoğunluğu yerel olarak görünseler de etkileri küresel ölçektedir. Bunun başlıca nedeni, insanın çevreye karşı tutumudur. Türkiye'de çevre koruma ile ilgili yapılan çalışmalar genellikle kamuoyunun çevre ile ilgili bilgisinin arttırılması şeklinde olmuştur. Bu çalışmada çevresel mitlerin bireylerin çevrenin korunmasına yönelik düşüncelerini ne şekilde etkilediğinin belirlenmesi amaçlanmıştır. Burada katılımcılar tarafından çevre korumayla ilgili bileşenlerin özümsenip özümsenmediği araştırılmıştır.

\section{YÖNTEM}

\section{Araştırmanın Modeli}

Bu araştırmada nitel araştırma yöntemi kullanılmış ve elde edilen veriler içerik analizi yapılarak değerlendirilmiştir. Nitel araştırmaların en büyük avantajı araştırmada esneklik sağlamasıdır. Çünkü bu tür araştırmalarda ilave sorulara gereksinim duyulabilir, çalışmanın sınırları değiştirilebilir. Nitel araştırmalar odaklanılan problemi kendi kulvarında yorumlarken onlara atfedilen manaları da göz önünde bulundurur. Nitel araştırmalar düşünsel fonksiyonları geliştirir (Malterud, 2001). Nitel araştırmaların planlanması ve uygulamaya koyulması sürecinde araştırmacılar, yaratıcı düşünme becerilerini kullanabilmektedirler (Guba ve Lincoln, 1994).

\section{Örneklem}

Araştırma 2017-2018 eğitim öğretim yılı güz döneminde dört farklı şehirde bulunan yedi devlet okulu ve bir özel okulda öğrenim gören 400 lise öğrencisi ile gerçekleştirilmiştir. Okullar arasında; fen 
lisesi, Anadolu lisesi, meslek lisesi ve imam hatip lisesi yer almaktadır. Liselerin tüm sınıf kademelerine uygulanmıştır.

Araştırma grubunun \%64.25'ini kadınlar, \%35.75'ini erkekler oluştururken araştırmanın \%25'i özel okullarda, \%75'i ise devlet okullarında gerçekleştirilmiştir. Uygulama okullarının \%10'unu Fen Liseleri, \%37.5'ini Anadolu Liseleri, \%5'ini Anadolu İmam Hatip Liseleri ve \%47.5'ini ise Meslek Liseleri oluşturmaktadır.

\section{Veri Toplama Aracı}

Veriler yarı yapılandırılmış görüşme formu kullanılarak elde edilmiştir. Veri toplama aracında yer alan senaryolar, alanyazın taraması neticesinde geliştirilmiştir. Senaryolar basın yayın organları aracılı̆̆ıla detaylandırılmıştır. Senaryolara yönelik sorular oluşturulurken anlaşılırlık, uygulanabilirlik ve güvenirlik ilkelerini teyit etmek amaciyla uzman görüşüne başvurulmuştur. Görüşme formunun geçerlik ve güvenirliği üç uzmanın görüşü ile sağlanmıştır.

\section{Okuma Parçası: "Şanlıurfa'daki Balıklı Göl"}

Şanlıurfa sinırlarmda bulunan Balıklı Göl, 450 m²'likbir alana sahiptir. Dilden dile nesilden nesile anlatılan efsanelerin konusu olmuş bazı balkkları bulundurur. Kur'an'da, Hz. İbrahim'in Nemrut ile yaşadığı olay Balkkl Göl ile ilişkilendirilerek detaylı olarak ifade edilmiştir. Balkkı Göl'ün kutsal bir mekân olarak kabul edilme nedeni Hz. İbrahim ateşe düştüğ̈̈nde, ateşin suya, odunlarn da balı̆ga dönüştüğ̈̈ne inanilmasıdır. Bu gölde yaşayan balkklara kutsiyet atfedilmiştir. Ĕğer bu baliklar yenecek olursa günah işleneceğine inanilmaktadır. Bu baliklar besin olarak tüketildiğinde tüketen kişinin başına pek çok kötülü̈k ve bela geleceğine inanlmaktadır. Bu balkklara dokunanlarn tenlerinde yaralar oluşacağına dair bir inanç mevcuttur. Önceleri bu baliklarn yemeye tenezzül eden kişilerin yaşadıklan belalar, halk arasında korku ve kutsiyet içerisinde konuşulmaktadır. Belki de Balıkl Göl'ün doğal halini koruyarak günümüze kadar varlğ̆ın sürdürebilmesi bu sayededir. Aynca dua etme ve dilek tutma gibi çeşitli sebeplerle bu gölde bulunan bahklara yem atmak büyük sevap kazandıran bir iş olarak kabul edilmektedir. Bu sayede dua ve isteklerin kabul edileceğine inanılmaktadır. Yemi yiyen balı, yemi atan kişiye sırtın gösterirse arzusunun gerçekleşeceğine işaret ettiği düşünülmektedir. Tüm bu özellikleri ile Balklı Göl, yıl boyunca yerli ve yabancı çok sayıda ziyaretçiye ev sahipliği yapmaktadır (Özpay, 2017).

Bu okuma parçasına göre Balıklı Göl'ün kutsal bir mekân olarak kabul edilmesini; araştırmada Şanlıurfa' daki Balıklı Göl senaryosuna yönelik “Bu alanın doğal güzelliklerinin ve türlerinin korunması açısından nasıl değerlendirirsiniz?" sorusuna cevap aranmıştır. Elde edilen bulgular ve örnek öğrenci görüşleri Tablo 1'de verilmiştir.

\section{Okuma Parçası: "İscehisar-Bakacak Dağı"}

Bakacak Dağı, Afyon-İscehisar İlçesinin Alanyurt Köyü'nde yer almaktadır. Köyün yukarı kısmında bulunan Bakacak Dağı'nın zirvesinde Kurtuluş Savaşında şehit olan bir askerimizin mezarı bulunmaktadır. Yöre halkı, Şehidimizin bu dağı koruduğuna inanmaktadır. Bu dağdan getirilen taşın, 
kesilen ağacın, avlanan hayvanın, toplanan kozalağın kısaca bu dağdan alınan bütün varlkkların uğursuzluk getirdiği düşünülmektedir. Bu düşünceyi göz ardn eden insanlarn başlarına çeşitli felaketlerin geldiği halk arasında anlatılmaktadır. Bu durumu bilen yöre ve çevre halkı Bakacak Dă̆ı' na karşı saygı duymakta ve bu dağa ait olduğunu düşündüğü canlı ve cansız varliklar korumaktadır. Bakacak Dă̆ı'nda hayvanlar ve diğer canlllar insan tehdidi olmaksızın güvenle yaşamakta ve üremektedir. Çünkü bu dağda avcılık ve ürün toplama faaliyetleri yapılmamaktadır. Bakacak Dă̆ı'nın yakınlarındaki diğer yaşam alanlarından avcılık baskısıyla kaçan hayvanlar da bu dağa sığınmaktadır. Bir av hayvanını takip eden avcı, av bu dağa kaçtıktan sonra avın takibini bırakmaktadır (Bu hikâye yerel halk ile yapılan görüşmeler sonucunda oluşturulmuştur).

Bu okuma parçasına göre yöre halkının Bakacak Dağı'na karşı sahip olduğu tutum ve davranışlarını; araştırmada İscehisar Bakacak Dağı'na yönelik “Bakacak Dağı'ndaki biyolojik çeşitliliği etkilemesi açısından nasıl değerlendirirsiniz?" sorusuna cevap aranmıştır. Elde edilen bulgular ve örnek öğrenci görüşleri Tablo 3'de verilmiştir.

\section{Okuma Parçası: “Asker Balıklar"}

Çankırl-Atkaracalar ilçesinin Ilıpınar köyünde yöre halkı tarafindan "Asker Balıklar" diye adlandırlan balıklar bulunmaktadır. Çanakkale Savaşı sırasında bu havuzlarda sadece dokuz balık kalmıştır. Savaş sonrasında balıklar vücutlarının çeşitli yerlerinde yaralar olduğu halde geri dönmüşlerdir. Bu görüntü balıklarm halk tarafindan "Asker Balıklar" olarak adlandırlmasına neden olmuştur. 1974 Kıbrıs Barış Harekâtı'nda balık sayısı bariz olarak azalmıştır. Harekât üç buçuk ay sürmüş ve harekât bitince balıklar yara alarak geri gelmişlerdir. Günümüzde de yöre halkı bu balikların sayısının Türk Ordusu'nun harekâtlarıyla değişim gösterdiğine inanmaktadır. Atkaracalar'da görev yapmak üzere atanan bir memur, balıklardan yakalamak istemiş. Balikların kutsal hikâyelerine aldırış etmemiş. Yakaladığı balıkları eve götürmüş ve eşi tavaya koymuş. Fakat balıklar kaybolmuş. Memur da o gece hayatın kaybetmiş. Köylülerin anlattığına göre, balıklar doğal yolla ölse bile kedi ve köpekler asla tüketmezler. Burada ölen balıklar insanlar tarafindan defnedilir. Bu balıklarm bulunduğu sular da özeldir. Sedef ve mantar hastalıklarnna, eklem ağrilarına şifa vermektedir. Bu suyun sürekli olarak analizi yapılmakta ve mikrobik bir bulguya da rastlanılmamaktadır. Havuzdaki suyun mantar, sedef gibi cilt hastaliklarnna faydah olduğu yüzlerce kişi tarafından kullanılarak kanıtlanmıştır (Kumartaşlığlu, 2020; Karaköse, 2015).

Bu okuma parçasına göre yöre halkının bu balıkları "Asker Balıklar" olarak adlandırarak onlara saygı duymalarının; araştırmada Asker Balıklar senaryosuna yönelik "Bu balıklar açısından sağladığı faydaları nasıl değerlendirirsiniz?" sorusuna cevap aranmıştır. Elde edilen bulgular ve örnek öğrenci görüşleri Tablo 4'de verilmiştir. 


\section{Okuma Parçası: “Güvercin ve Örümcek”}

Peygamberimiz Hz. Muhammed, Mekke'den Medine'ye göç ederken kendisini öldürmek için izleyen müşriklerden kurtulmak amacıyla Hz. Ebû Bekir ile birlikte Sevr Dağı'ndaki bir mağaraya sığınmıştır. Bundan sonra bir örümcek mağaranın giriş kısmına ağ örmüş, bir çift güvercin de mağaranın bulunduğu yerdeki ağaç dalları üzerine kendileri için bir yuva yapmıştır. Ayrıca dişi güvercin de bu yuvaya yumurtalar bırakmıştır. Mağara girişinde hiç zarar görmemiş örümcek ağını, yuvadaki güvercinleri ve yumurtalarmı gören müşrikler mağaraya kimsenin girmiş olamayacağını düşünerek oradan uzaklaşmışlardır. İslam ülkelerinde, güvercinlerin bu davranışından dolayı cami, kule ve sur yapılarının içine güvercinlerin barınması için yuvalar yapılmakta, evlerde görülen örümcekler ise zarar verilmeden özenle dış ortamdaki uygun alanlara bırakılmaktadır (Şener, 2004).

Peygamberimizin yaşadığı bu olaydan hareketle; araştırmada Güvercin ve Örümcek senaryosuna yönelik “İnsanlar açısından sağladığı faydaları yazınız." sorusuna cevap aranmıştır. Elde edilen bulgular ve örnek öğrenci görüşleri Tablo 6' da verilmiştir.

\section{Verilerin Analizi}

Elde edilen veriler içerik analizi yöntemi ile değerlendirilmiştir. İçerik analizleri; araştrılan konunun yayginlaştırılması ve daha sonraki araştırmaların yönlendirilmesinde etkilidir (Suri ve Clarke, 2009). İçerik analizi, iletişimin sunulan verilerinin yansız, kategorize edilmiş halidir (Berelson, 1952). İçerik analizinde temel amaç, elde edilen verileri yorumlayabilmek ve aralarında ilinti oluşturmaktır. İçerik analizinde veriler belirli temalar altında kategorize edilerek yorumlanır (Yıldırım veŞimşek, 2006). Verilerin analizinde, alanyazın taramasına uygun olarak tüm uygulama sonuçları itina ile kategorize edilmiştir. Veriler analiz edilirken alanyazın doğrultusunda kodlamalar ve senaryolara özgü temalar oluşturulmuştur. Elde edilen veriler oluşturulan temalar altında sınıflandırılmıştır.

\section{BULGULAR}

Öğrencilere dört farklı okuma parçası verilerek okumaları ve sonrasında hazırlanan sorulara içtenlikle cevap vermeleri istenmiştir.

Tablo 1.

Balıklı Göl' ü, Doğal Güzelliklerinin ve Türlerinin Korunması Açısından Nasıl Değerlendirirsiniz?

\begin{tabular}{|c|c|c|c|}
\hline Ana Tema & $f$ & $\%$ & Örnek Öğrrenci Görüssleri \\
\hline 1. Kutsal kabul edilenyerlerdeki türler korunur. & 116 & 29 & $\begin{array}{l}\text { Ö-14 Bazı yerlerin } \\
\text { dokunulmazhı̆̆ vardır. } \\
\text { Ö-367 Sadece kutsal hikâyesi } \\
\text { olan yerlere daha saygılı } \\
\text { davranmamız ne kadar üzücü. } \\
\text { Ö-183 Balıklı Göl kutsaldır. } \\
\text { Ö-319 Bu türler kutsal sayıldı̆̆ı } \\
\text { için nesli tükenmez. }\end{array}$ \\
\hline
\end{tabular}


Tablo 1 (Devam)

\begin{tabular}{|c|c|c|c|}
\hline 2. Bir yerin korunmasında dini inançlar önemli rol oynar. & 82 & 20,5 & $\begin{array}{l}\text { Ö-284 Dini inanışlar } \\
\text { Güncel hayatımızda } \\
\text { çevrenin } \\
\text { korunmasına } \\
\text { yardımcı olur. } \\
\text { Ö-42r Dinimiz } \\
\text { insanlara, tüm } \\
\text { canlılarar saygı } \\
\text { duymayı ögretmiştir. } \\
\text { Ö-26 Küçüken } \\
\text { anneannemden } \\
\text { dinlediğim dini } \\
\text { hikâyeler benim } \\
\text { doğasever olmamda } \\
\text { etkili oldu. } \\
\end{array}$ \\
\hline 3. İnsan elinin değmediği yerler bozulmuyor. & 150 & 37,5 & $\begin{array}{l}\text { Ö-23 İnsan elinin } \\
\text { değmediği yerler } \\
\text { doğallı̆̆ıı koruyor. } \\
\text { Ö-67 Balıklarn } \\
\text { yumurtlama } \\
\text { döneminde } \\
\text { katledilmesi } \\
\text { önlenmişolur. } \\
\text { Ö-383 Bizler daha } \\
\text { dikkatli davransak } \\
\text { çevre bozulmazdi. }\end{array}$ \\
\hline 4. Böyle hikâyelerin sayısı artmalıdır. & 52 & 13 & $\begin{array}{l}\text { Ö-168 İnsanların } \\
\text { dikkatini çektiği için } \\
\text { turizm } \\
\text { faaliyetlerinin } \\
\text { artmasina neden } \\
\text { olur. }\end{array}$ \\
\hline
\end{tabular}

Tablo 1 incelendiğinde, \%29 oranında bir yerin kutsal kabul edilmesinin, o alanda bulunan türlerin de korunmasını sağladığı görüşüne varılmıştır. Ayrıca bir yerin korunmasında bölgenin dini inanışı ve kültürünün de etkin rol oynadığı gözlenmiştir. Uygulamanın yapıldığı katılımcıların \%37,5' i öz eleştiri yaparak insan türünün doğal güzelliklere zarar verdiği şeklinde görüş bildirmiştir. Dini inançların çevre korumada etkili olduğu görüşü ise \%20,5 olarak belirlenmiştir. Uygulamada yer alan mitlerin sayıca artması gerektiği de \%13 oranı ile görüşler arasında yerini almıştır.

Araştırmada Şanlıurfa'daki Balıklı Göl senaryosuna yönelik “Ekoturizm açısından sağladığı faydaları nasıl değerlendirirsiniz?" sorusuna cevap aranmıştır. Elde edilen bulgular ve örnek öğrenci görüşleri Tablo 2' de verilmiştir. 
Tablo 2.

Eko-Turizm Açısından Sağladı̆̆ 1 Olumlu Etkileri Nasıl Değerlendirirsiniz?

\begin{tabular}{|c|c|c|c|}
\hline Ana Tema & f & $\%$ & Örnek Öğrenci Görüşleri \\
\hline 1.Bölgeye maddi gelir sağlar. & 194 & 48,5 & $\begin{array}{l}\text { Ö-8 Yabancı turistler döviz getirir. Hem bölge } \\
\text { halkı hem ülke kazanır. } \\
\text { Ö-22 Buraya yapılan ziyaretler farklı iş } \\
\text { dallarında gelir săglar. } \\
\text { Ö-61 Şanlıurfa'ya gelir să̆lar. }\end{array}$ \\
\hline $\begin{array}{l}\text { 2. Farklı kültürlerin bir araya } \\
\text { gelmesini sağlar. }\end{array}$ & 106 & 26,5 & $\begin{array}{l}\text { Ö-32 Kültürel gelişime katkı să̆lamıştır. } \\
\text { Ö-45 Farklı bir inanışa sahip olanların da } \\
\text { ilgisini çeker. } \\
\text { O-273 Yurtdışından gelenler kendi memleketleri } \\
\text { ile kıyas yapar. }\end{array}$ \\
\hline 3. İnsanlara istihdam sağlar. & 57 & 14,25 & $\begin{array}{l}\text { Ö-134 İnsanlar iş sahibi olur. } \\
\text { Ö-397 Buranın hikâyesini anlatan çocuklar var. } \\
\text { Ö-147 Ekoturizmi olumlu etkiler. }\end{array}$ \\
\hline $\begin{array}{l}\text { 4. İslam dini herkese tanıtılır, } \\
\text { daha da güçlenir. }\end{array}$ & 43 & 10,75 & $\begin{array}{l}\text { Ö-197 Íslam dini farklı kültürlere tanıtılmış } \\
\text { olur. } \\
\text { Ö-14 Bilmeyenler için bazı kutsal değerimiz de } \\
\text { tanıtılmış olur. } \\
\text { Ö-185 Canlılara ne kadar önem veren bir } \\
\text { dinimiz olduğunu gösterir. }\end{array}$ \\
\hline Toplam & 400 & 100 & \\
\hline
\end{tabular}

Tablo 2'ye göre verilen mitin ekoturizm açısından değerlendirilmesi istenmiş ve \%48,5 oranında bölgeye maddi gelir sağladığı, \%26,5 oranında farklı kültürlerin bir araya gelmesini sağladığı, \%14,25 oranında insanlara istihdam sağladığı, \%10,75 oranında ise İslam dininin herkese tanıtılıp daha da güçlendiği sonucuna varılmıştır.

Tablo 3.

Bakacak Dağı'ndaki Biyolojik Çeşitliliği Etkilemesi Açısından Nasıl Değerlendirirsiniz?

\begin{tabular}{|c|c|c|c|}
\hline Ana Tema & f & $\%$ & Örnek Öğrenci Görüşleri \\
\hline \multirow[t]{2}{*}{ 1. Biyolojik çeşitlilik korunur } & \multirow[t]{2}{*}{20} & \multirow[t]{2}{*}{5} & $\begin{array}{l}\text { Ö-22 Ekosistem bozulmaz, biyoçeşitlilik korunur. } \\
\text { Ö-23 Türk Milleti asker bir millet olduğundan } \\
\text { şehidine ve bölgeye sahip çıkmış bölgenin türlerini } \\
\text { korumuștur. }\end{array}$ \\
\hline & & & $\begin{array}{l}\text { Ö-69 Köy halkının ağaçlan kesmemesi } \\
\text { fotosentezin devam etmesini ve bölgenin havasının } \\
\text { temiz kalmasını sağlamıştır }\end{array}$ \\
\hline \multirow{2}{*}{$\begin{array}{l}\text { 2. Avcilığ } 1 \text { önlemek için güzel } \\
\text { bir yöntem. }\end{array}$} & \multirow[t]{2}{*}{143} & \multirow[t]{2}{*}{35,75} & $\begin{array}{l}\text { Ö-16 Avcılık denen katliam önlenmiş olur. } \\
\text { Ö-392 Eskiden beri avcılık yapanlar bu hikâyeleri } \\
\text { bilse yapmazlardı. }\end{array}$ \\
\hline & & & $\begin{array}{l}\text { Ö-44 Avcilıktan uzaklaştırıp farklı yollara } \\
\text { yönlendirir. }\end{array}$ \\
\hline $\begin{array}{l}\text { 3. Tüm dünya bu hikâyelerle } \\
\text { korunabilir. }\end{array}$ & 51 & 12,75 & $\begin{array}{l}\text { Ö-77 Bu hikâyeler diğer uluslarda da olsa } \\
\text { dünyadaki canlılar korunabilirdi. } \\
\text { Ö-98 Her bölgede böyle hikâyeler anlatılmalı. } \\
\text { Ö-11 Hiçbir canlı uğursuzluk getirmez. } \\
\text { Canlılarn birbirine ihtiyacı vardır. }\end{array}$ \\
\hline Toplam & 400 & 100 & \\
\hline
\end{tabular}


Tablo 3 incelendiğinde; \%51,5 oranında ilgili mitin Bakacak Dağı'ndaki biyolojik çeşitliliği koruduğu, \%35,75 oranında avcılığı önlediği ve \%12,75 oranında da tüm Dünyanın bu mitlerle korunabileceği görüşü ortaya çıkmıştır.

Tablo 4.

Bu Balıklar Açısından Sağladığı Faydaları Nasıl Değerlendirirsiniz?

\begin{tabular}{|c|c|c|c|}
\hline Ana Tema & f & $\%$ & Örnek Öğrenci Görüşleri \\
\hline $\begin{array}{l}\text { 1. Balıklar tehlikelerden } \\
\text { uzak yaşarlar ve ekosistem } \\
\text { bozulmaz. }\end{array}$ & 245 & 61,25 & $\begin{array}{l}\text { Ö-78 Üzerinde çalışılırsa geleceğe yönelik tedavi } \\
\text { yöntemleri bulunabilir. } \\
\text { Ö-93 İnsanlarda doğaya karşı vefayı arttırmıştır. } \\
\text { Ö-107 İnsanlar doğayı daha az tahrip eder. } \\
\text { Böylece gelecek nesillere daha güzel bir dünya } \\
\text { bırakılır. }\end{array}$ \\
\hline $\begin{array}{l}2 . \quad \text { Ekolojik } \\
\text { sağlanmıştır. }\end{array}$ & 83 & 20,75 & $\begin{array}{l}\text { Ö-40 Balıklar korundukları için havuz } \\
\text { insanoğluna şifa hediye etmiştir. } \\
\text { Ö-46 Bir tür korunduğunda onunla beslenen tür } \\
\text { de korunur. } \\
\text { Ö-383 Doğanın dengesi bozulmamış olur. }\end{array}$ \\
\hline $\begin{array}{l}\text { 3. Balıkların populasyon } \\
\text { büyüklüğüu artmıştır. }\end{array}$ & 72 & 18 & $\begin{array}{l}\text { Ö-88 Balıklar öldürülmediğinden üreme } \\
\text { döneminde çoğalabilirler. } \\
\text { Ö-451 Balıklar türlerinin devamlılı̆̆ını } \\
\text { sağlayabilir. }\end{array}$ \\
\hline Toplam & 400 & 100 & \\
\hline
\end{tabular}

Tablo 4 incelendiğinde, \%61,25 oranında ekosistemin bozulmasının önlendiği, \%20,25 oranında ekolojik dengenin sağlandığı, \%18 oranında ise balık popülasyonunun arttı̆̆ına dair yorumlara rastlanmıştır.

Araştırmada Asker Balıklar senaryosuna yönelik "İnsanlar açısından sağladığı faydaları yazınız." sorusuna cevap aranmıştır. Elde edilen bulgular ve örnek öğrenci görüşleri Tablo 5'de verilmiştir.

Tablo 5. İnsanlar Açısından Sağladığı Faydalar

\begin{tabular}{|c|c|c|c|}
\hline Ana Tema & $f$ & $\%$ & Örnek Öğrenci Görüşleri \\
\hline 1. Ekoturizme faydalı olmuştur. & 228 & 57 & $\begin{array}{l}\text { Ö-78 Bu hikâye bölgeyi ilgi çekici hale } \\
\text { getirmiştir. } \\
\text { Ö-267 Bölge turistik hale gelmiştir. } \\
\text { Ö-14 Turizmde değerlendirilebilir. }\end{array}$ \\
\hline 2. Çevre bilinci kazandırmıştır. & 97 & 24,25 & $\begin{array}{l}\text { Ö-25 Insanların bilinçlenmesine katkı } \\
\text { să̆lamıştır. } \\
\text { Ö-65 Insanların çevreye daha duyarlı } \\
\text { yaklaşmalarını sağlar. } \\
\text { Ö-78 Herkes doğadaki her canlıya saygı } \\
\text { duymayı ögrensin. }\end{array}$ \\
\hline 3. Hastalıklara şifa olmuştur. & 75 & 18,75 & $\begin{array}{l}\text { Ö-42 Buranın yanına hastane yapıp } \\
\text { faydalanılmalı. } \\
\text { Ö-366 Alternatif tıp yöntemlerine dâhil } \\
\text { edilebilir. } \\
\text { Ö-32 Doğaya zarar vermesek o bize yardımon } \\
\text { olur. Şifa verir. }\end{array}$ \\
\hline Toplam & 400 & 100 & \\
\hline
\end{tabular}


Tablo 5'e göre öğrenciler, ilgili mitin \%57 oranında ekoturizme faydalı olduğu, \%24,25 oranında çevre bilinci kazandırdığı ve \%18,75 oranında ise hastalıklara şifa olduğu yönünde görüş bildirmişlerdir.

Tablo 6.

İnsanlar Açısından Sağladığı Faydalar

\begin{tabular}{|c|c|c|c|}
\hline Ana Tema & $\mathbf{f}$ & $\%$ & Örnek Öğrenci Görüşleri \\
\hline 1. Canlılara duyulan saygı artacaktır. & 189 & 47,25 & $\begin{array}{l}\text { Ö-92 Bu durum ekosistemde } \\
\text { kalmalarına ve çevreye uyum } \\
\text { sağlamalarına yardımcı olup yaşama } \\
\text { şanslarını arttırarak canlı türlerinin } \\
\text { korunmasına yardımcı olur. } \\
\text { Ö-66 Dini öğretiler her cana değer } \\
\text { verir. } \\
\text { Ö-81 Herkesin bu hikâyeyi } \\
\text { öğrenmesi çevresindekilere de saygı } \\
\text { duyması gerekir. }\end{array}$ \\
\hline 2. Bu canlıların nesli tükenmekten kurtulur. & 131 & 32,75 & $\begin{array}{l}\text { Ö-7 Bölgedeki canlıların çevreye } \\
\text { uyum yeteneği artmıştır. } \\
\text { Ö-65 Bu olayı herkes bilseydi } \\
\text { canlıların nesli tükenmezdi. } \\
\text { Ö-326 Canlıları öldürmek ve yok } \\
\text { etmek hiçbir insana yakışmaz. }\end{array}$ \\
\hline 3. Tüm canlıların yaşamı birbirine bağlıdır. & 75 & 18,75 & $\begin{array}{l}\text { Ö-111 Bir insan ufacık bir hayvanın } \\
\text { yardımına bile ihtiyaç duyabilir. } \\
\text { Ö-43 Tüm canlıların yaşamı } \\
\text { birbirine bağlıdır. Birine verilecek } \\
\text { zarar düzeni bozar. }\end{array}$ \\
\hline 4. Diğer & 45 & 11,25 & $\begin{array}{l}\text { Ö-164 Dinimiz bize güzel şeyler } \\
\text { öğretir. } \\
\text { Ö-93 Bu yöntemler türleri korumak } \\
\text { için iyi bir fikir olabilir. } \\
\text { Ö-319 Sadece örümcekler değil tüm } \\
\text { canlılar değerlidir. }\end{array}$ \\
\hline Toplam & 400 & 100 & \\
\hline
\end{tabular}

Tablo 6'ya göre, \%42,25 oranında ilgili mitin canlılara duyulan saygıyı arttıracağı, \%27,75 oranında bu canlıların neslinin tükenmekten kurtulacağı, \%18,75 oranında ise tüm canlıların yaşamlarının birbirine bağlı olduğu görüşüne rastlanmıştır. Bu kategorilere dâhil edilmeyen yorumlar ise $\% 11,25$ oranında olup diğer başlık altında toplanmıştır.

\section{TARTIŞMA VE SONUÇ}

Bu çalışmada çevre ile ilgili mitolojik hikâyelerin, ilgili bölgelerde yaşayan ve bu hikâyeleri bilen insanlar üzerinde, hikâyelerde sözü edilen canlı türlerinin korunmasına etkisinin olup olmadığı araştııılmıştır. Bu amaçla araştırmacı tarafından alanyazına dayalı olarak derlenmiş olan dört mitolojik öykü ve bunlarla ilgili sorular, beş farklı lise türünde öğrenim gören dört yüz öğrenciye uygulanmıştır. 
Mitolojik hikâyeler bölgesel olarak değerlendirildiğinde özellikle kendi yöresine ait hikâyeyi değerlendiren öğrenciler, o mite hâkim oldukları ve o kültürle yetiştikleri için oldukça titiz cevaplar vermişlerdir. Ayrıca yazılan yorumlardan, ilgili mitin onlar için kutsal olduğu çıkarımı yapılmıştır. Örneğin Şanlıurfa Balıklı göl miti, Şanlıurfa'da yaşayan öğrenciler tarafından oldukça önemli kabul edilmektedir. Ayrıca kendi yaşadığı bölgede böyle mitolojik hikâyeler olan öğrenciler uygulamaya daha itinalı ve istekli cevaplar vermişlerdir. Elde edilen veriler doğrultusunda öğrencilerin yaşadıkları bölge ve yetiştikleri kültürün, doğaya ve mitlere bakış açılarında farklılıklara sebep olabildiği saptanmıştır. Yılmaz, Karakaya, Atilla ve Alakabak (2019) yaptıkları çalışmada öğrencilerin etik kavramlarda ahlaki yargı kavramlarının önemli olduğunu belirtmişlerdir.

Katılımcıların çevresel mitlere karşı tutumları yaşadıkları yere göre ve yaşadıkları bölgede çevre ile ilgili mitolojik hikâye olup olmamasına göre farklılıklar göstermiştir. Yaşadığı bölgede böyle bir mit bulunan öğrenciler genellikle bu durumu özümseyerek yetişmişler ve böyle mitlerin gerçekte meydana gelmiş olduğunu ifade etmişlerdir. Ayrıca bu öğrencilerin, çalışmada verilen diğer üç mite karşı tutumu da olumlu yönde olmuştur. Kendi kültürlerinde yer alan mitlerin onlara neler sağladığını ve diğer mitlerin de gerçekleştikleri yerlerde fayda sağlayacağını ifade etmişlerdir. Örneğin uygulama grubunun bir kısmını oluşturan, Şanlıurfa' da ikamet edip öğrenim gören öğrenciler balıklı göl mitinin bölge halkına hem sosyal hem manevi katk1 sağladığını ifade etmişlerdir. Orada bulunan balıkların avlanmaması ve herhangi bir zarar verilmeyerek kutsal kabul edilmesi bölge halkında kültürel bir değer haline gelmiştir. Şanlıurfa'ya dışarıdan gelen ziyaretçilere bunu bir övünç kaynağı olarak anlattıklarını belirtmişlerdir. Bununla birlikte öğrencilerin sosyoekonomik durumlarının da mitlere yaklaşımında farklılıklara neden olduğu gözlemlenmiştir. Elbette öğrencilerin özel ilgi alanları, takip ettikleri yayınlar ve yapımlar da çevrelerine atfettikleri değer üzerin etkili olmaktadır. Aynı zamanda bu mitin hemen her yaş grubu tarafından bilindiği ve herkesin bir sonraki kuşağa aktarmak için istekli olduğu gözlenmiştir. Topcu ve Polat (2018), çalışmalarında doğal unsurlara mitolojik yazınlar ile desteklenmesinin çevreye verilen zararı azaltacağını belirtmişlerdir. Alanyazında bu çalışmadaki sonuçları destekleyen bulgular yer almaktadır (Gacar, 2020; Holil, 2020; Karakaya, Atilla, Alakabak ve Yılmaz, 2019; Maru, Gebrekirstos ve Haile, 2020).

Turizm sayesinde insanlar ziyaret ettikleri bölgelerin sadece güzelliklerini değil geçmişten günümüze insanların bırakmış olduğu kültürel mirasın da farkına vararak bilinçlenirler. Son dönemlerde insanların turizm eğilimlerinin alışılagelenden eğlence, eğitim ve çevre üçlüsüne yöneldiği görülmektedir (Kurt ve Kurdoğlu, 2016; Konakoğlu ve Kurdoğlu, 2020).

Turizm ile kültür arasında çok güçlü bir ilişki vardır. Kültürel mirasın zenginliği bir bölgenin turizm amaçlı çekiciliğini artırmaktadır. Bir bölgedeki yaşam biçimleri, gelenekler, 
görenekler, festivaller, müzik, el sanatları, tarih, din gibi birçok bileşen turizm bağlamında insanların ilgisini çekmektedir (Kurt, Düzgüneş, Kurdoğlu ve Demirel, 2016).

Ekoturizmin sosyal ve kültürel faydaları arasında doğal ve kültürel mirasın korunması ve yozlaşmanın önüne geçilmesinin yer aldığı belirtilmektedir (Ankaya, Yazıcı, Balık ve Aslan, 2018). Çeşitli turizm dallarının ilgili alanlarda ziyaretçileri bilgilendirme ve eğlendirmenin yanında bölgenin korunması konusunda da bilinçlendirmeye neden olacağı düşünülmektedir.

Ekosistemin korunması için üretilebilecek alternatif yöntemlere tüm insanlık önem vermelidir. Doğaya verilen zararın azaltılması için böyle mitolojik hikâyeler ve diğer mitoloji temalı edebi eserlerin eğitimde ve yaşamın diğer alanlarında kullanılmasının olumlu yönde etkili olacağı düşünülmektedir.

\section{ÖNERILER}

Bu çalışmada elde edilen sonuçlar dikkate alındığında aşağıdakiler önerilmektedir:

- Doğanın, canlının korunmasına ve onlara değer atfedilmesine yönelik bu tip mitolojik hikâyelere MEB kontrolünde etkinlik olarak yer verilebilir.

- Bu hikâyelerin, öğrencilerin ilgisini çekecek şekilde eğitici animasyonları hazırlanabilir. Ders girişinde dikkat çekme etkinliği olarak kullanılabilir.

- Bu tür hikâyeler, çevre koruma ve kamuoyunun bilinçlendirilmesi ile ilgili çalışmalarda kullanılabilir.

- Bu tür hikâyelere konu olan doğal yaşam alanlarının korunmasında yetkili kurum ve kuruluşların koordineli çalışmaları ve MEB'in mutlaka paydaşlar arasında yer almasının gerekli olduğu düşünülmektedir.

- Bu tür hikayelerin ekoturizm, kültür turizmi ve inanç turizmi alanlarında da değerlendirilebileceği düşünülmektedir.

\section{KAYNAKÇA}

Aikenhead, G. (1991). Logical resoning in science and technology. New York: John Wiley and Sons.

Albayrak, A. (2017). Mitolojinin dini hayattaki yeri ve önemi. Uluslararası Sosyal Araştırmalar Dergisi, 10(54), 951-954

Altunışık, R., Coşkun. R., Bayraktaroğlu, S., \& Yıldırım, E. (2010). Sosyal bilimlerde araştırma yöntemleri SPSS uygulamalı (6. Baskı). Sakarya: Ekin.

Ankaya, F., Yazıcı, K., Balık, G., \& Aslan B. (2018). Dünyada ve Türkiye'de ekoturizm, sosyalkültürel ve ekonomik katkıları. Ulusal Çevre Bilimleri Araştırma Dergisi, 1(2), 69-72.

Argyris, C., \& Schon, D.A. (1978). Organizational learning. USA: Reading.

Artun, E. (1998). Tekirdağ'da batıl inanışlar. Tekirdă̆ Halk Kültürü Araştırmaları, 1(1), 66-83.

Baltacı, A. (2019). Nitel araştırma süreci: Nitel bir araştırma nasıl yapılır? Ahi Evran Üniversitesi Sosyal Bilimler Enstitüsü Dergisi, 5, 368-388. 
Baylan, E. (2009). Doğaya ilişkin inançlar, kültür ve çevre sorunları arasındaki ilişkilerin kuramsal bağlamda irdelenmesi. Ankara Üniversitesi Çevre Bilimleri Dergisi, 1, 67-74.

Berelson, B. (1952). Content analysis in communication research. Glencoe: Free Press.

Boratav, P. (1992). 100 Soruda Türk halk edebiyatı. İstanbul: Bilgesu.

Büyüköztürk, Ş., Kılıç Çakmak, E., Akgün, Ö. E., Karademir, Ş., \& Demirel, F. (2010). Bilimsel araştırma yöntemleri (6. Baskı). Ankara: Pegem.

Carey, S. (1985). Conceptual change in childhood. Cambridge: MA, MIT.

Çetin, Ç. (2007) Tatar Türkleri'nde mitolojik varlıklarla ilgili mitler ve inanışlar: İyeler ve yaratıklar. Türk Dünyası Sosyal Bilimler Dergisi, 1(43), 1-32.

Çimen, O., \& Timur, S. (2013). Öğretmen adaylarının çevreye yönelik olumsuz davranışlarının incelenmesi. International Periodical for the Languages, Literature and History of Turkish or Turkic Volume, 8(12), 335-346

Çoruhlu, Y. (1999). Türk mitolojisinin ABC'si. İstanbul: Kabalc1.

Derman, A., \& Aslan, Z. (2016). Çevre eğitimi için kültürel bir bakış açısı: Dede Korkut Hikayeleri. Turkish Studies International Periodical for the Languages, Literature and History of Turkish or Turkic Volume, 11(14), 201-220.

Devers, K. J., \& Frankel, R. M. (2000). Study design in qualitative research--2: Sampling and data collection strategies. Education for Health, 13(2), 263.

Dreyfus, A. (1995). Biological knowledge as a prequisite for the development of values and attitudes. Journal of Biological Education, 29(3), 215-219.

Ergin, E. (2014). Biyoçeşitlilik ve koruma biyolojisi. http://www.bilimgenc.tubitak.gov.tr/makalebiyocesitlilik-ve-koruma-biyolojisi. 22.09.2020.

Erlich, P. R., \& Wilson, O.E. (1991). Biyoçeşitlilik çalışmaları: Bilim ve politika. Science, 253, 758-762.

Gacar, Ş. (2020). Hayvan folkloru bağlamında Türk dünyası ekolojik destanları. Erişim adresi: http:/ / www.openaccess.hacettepe.edu.tr:8080/xmlui/ bitstream/handle/11655/22853/ GACAR\%2c\%20\%c5\%9eamil\%20\%282020\%29.\%20Hayvan\%20Folkloru\%20Ba\%c4\%9fla m\%c4\%b1nda\%20T\%c3\%bcrk\%20D\%c3\%bcnyas\%c4\%b1\%20Ekolojik\%20Destanlar\%c4\% b1yeniii.pdf?sequence=4\&isAllowed=y. 18.09.2021.

Guba, E. G. \& Lincoln, Y. S. (1994). Competing paradigms in qualitative research. Handbook of Qualitative Research, 2(105), 163-194.

Gültekin, M. (2015). Dede Korkut Kitabı'nda kahramanların problem çözme yöntemleri ve Dede Korkut Kitabı'nın eğitimde kullanılması. Türk Dünyası İncelemeleri Dergisi/Journal of Turkish World Studies, 15(2), 49-54. 
Holil, M. (2020). Myths of Nyi Pohaci Sanghyang Sri on Sundanese Ethnic: Efforts to Reconstruct the Values of Environmental Conservation. IOP Conf. Series: Earth and Environmental Science, 469, 1-6.

Işık, K. (1996). $\quad$ Biyolojik çeşitlilik https://www.researchgate.net/profile/Kani_Isik/publication/215472338_BIYOLOJIK_C ESITLILIK/links/01de5c756ac613fd96d325e7/BIYOLOJIK-CESITLILIK.pdf. 08.09.2020.

İnan, A. (1976). Eski Türk dini tarihi. İstanbul: Kültür.

Janis, I.L. (1949). The problem of validating content analysis. New York. https:/ / books.google.com.tr/books?hl=tr\&lr=\&id=y1KEoBSqHMC\&oi=fnd\&pg=PA358\&dq=Janis,+I.L.+(1949).+The+problem+of+validatin $\mathrm{g}+$ content+analysis.+New+York.\&ots=kw3u3AruPY\&sig=U5a903oq_gfhksd0J05uwTA6 Olc\&redir_esc $=\mathrm{y} \# \mathrm{v}=$ onepage \&q\&f$=$ false $\cdot$ 07.09.2020.

Kafesoğlu, İ. (1993). Türk milli kültürü (10. Baskı). İstanbul: Boğaziçi.

Kalafat, Y. (1996). İslamiyet ve Türk halk inançları. Ankara: Kültür Bakanlığı.

Karakaş, R. (2012). Siirt halk kültürünün şifa dağıtıcıları: Kutsal sular. Turkish Studies International Periodical for the Languages, Literature and History of Turkish or Turkic Volume, 7(4), 2149-2161.

Karakaya, F., \& Arslan, O. (2016). Students'ethical approaches related to animal experiment: 9th grade example. Turkish Journal of Education, 5(4), 208-223.

Karakaya, F., Atilla, I., Alakabak, E.Z., \& Yılmaz, M. (2019). Ortaöğretim öğrencilerinin endemik türlere yönelik etik yaklaşımlarının belirlenmesi. Gazi Eğitim Bilimleri Dergisi, 5(3), 113-128.

Karaköse, S. (2015). Klasik Türk edebiyatında tenasüh inancı izleri. Atatürk Üniversitesi Türkiyat Araştırmaları Enstitüsü Dergisi, 54, 209-238.

Karakurt, D. (2011). Türk söylence sözlüğü, açıklamalı ansiklopedik mitoloji sözlüğü (2. Baskı). Türkiye: E-Kitap.

Keleş, F. (2017). Ortaokul öğrencileri için biyolojik çeşitlilik konusunda ders planı tasarlama. Adnan Menderes Üniversitesi Ĕ̆itim Fakültesi Eğitim Bilimleri Dergisi, 8(2), 41-65

Kılınçel, F. (2010). Bozkır'dan hikâyeler. Konya: Tebeşir.

KolayOf (t.y.). İlkçă̆ felsefesi. https:/ / www.kolayaof.com/ornek_ozet/FEL101U.pdf. 06.12.2019

Konakoğlu Kurt, S. S., \& Kurdoğlu, B. Ç. (2020). Doğa temelli turizm koridorlarının oluşturulmasına yönelik bir öneri: Amasya kent örneği, Turizm Akademik Dergisi, 7(1), 8395.

Kumartaşlığlu, S. (2020). Tayy-i mekan motifli efsanelerde savaşların gizli kahramanları. Milli Folklor, 32(16), 128.

Kurt, S. S., \& Kurdoğlu, B. Ç. (2016). The role and importance of tourism information system in urban tourism planning. Global Issues and Trends in Tourism, 1, 661-668. 
Kurt, S.S., Düzgüneş, E., Kurdoğlu, B. Ç., \& Demirel, Ö. (2016). Example study about meryemana valley (Trabzon/Turkey) for determining the potential campground in the scope of nature tourism. Journal of Environmental Protection and Ecology, 17(2), 576-583.

Malterud, K. (2001). Qualitative research: Standards, challenges, and guidelines. The Lancet, 358(9280), 483-488.

Mandaloğlu, M. (2013). Türk Mitolojisinden Anadolu'ya taşınan kültür: Geyik motifi. Uluslararası Araştırmalar Dergisi, 6(27), 382-391.

Maru, Y., Gebrekirstos, A. \& Haile, G. (2020). Indigenous ways of environmental protection in Gedeo community, Southern Ethiopia: A socio-ecological perspective. Cogent Food $\mathcal{E}$ Agriculture, 6(1), 1-26.

Meydan, A. \& Yıldız, N. (2014). 4.Sınıf sosyal bilgiler programındaki çevre ile ilişkilendirilen değerlerin öğrencilerin çevre bilinci kazanmasındaki önemi. Social Science Studies, 1, 50-64.

Mollaibrahimoğlu, Ç. (2008). Anadolu halk kültüründe hayvanlar etrafinda oluşan inanç ve pratikler. Yayınlanmamış Yüksek Lisans Tezi. Karadeniz Teknik Üniversitesi, Trabzon.

Morkoç, A. (2018). Cengiz Atymatov'un Dişi Kurdun Rüyaları romanında çevre felaketi. Manisa Celal Bayar Üniversitesi Sosyal Bilimler Dergisi, 16(1/2), 255-264.

Nar, M. (2014). Günümüz toplumunda mitler: Anadolu halk efsaneleri üzerine genel bir değerlendirme. Cyprus International University, 20(79), 55- 77.

Oğuz, D., Çakçı, I., \& Kavas, S. (2011). Yüksek öğretimde öğrencilerin çevre bilinci. Süleyman Demirel Üniversitesi Orman Fakültesi Dergisi, 12, 34-39.

Özpay A. G. (2017). Türkiye'de inanç turizmine yeni bir örnek: Kutsal Balıklı Göl. Atatürk Üniversitesi Sosyal Bilimler Enstitüsü Dergisi, 21(3), 937-951.

Polat, N. \& Topçu, T. (2018). Çevre sorunlarına mitler ışı̆̆ında çözüm önerileri. TÜBAR XLIV. Erişim adresi: https://dergipark.org.tr/en/download/article-file/610934

Pooley, J.A., \& O' Connor, M. (2000). Environment \& behavior. Environmental Education and Attitudes, 32(5), 711-724.

Şanlıurfa Balıklı Göl Videosuna https://www.youtube.com/watch?v=659bxrzrveE. html, 18.08.2019

Şener, H. İ. (2004). Hicretle ilgili şiirler ve tahlilleri. Dokuz Eylül Üniversitesi İlahiyat Fakültesi, 2(4), 89-103.

Seyidoğlu, B. (1995). Mitoloji üzerine araştırmalar/ Metinler ve tahliller. Kayseri: Bizim Gençlik.

Seyidoğlu, B. (1997). Erzurum efsaneleri. İstanbul: Dergâh.

Simon, E. J., Dickey, J. L., Hogan, K. A., \& Reece, J. B. (2017). Campbell temel biyoloji. Ankara: Palme.

Stone, P. J., Dunphy, D.C., Marshall, S. S., D. M., \& Ogilvie, D. M. (1966). The general inquirer: A computer aproach to content analysis. Massachusetts: The MIT.

Taplamacıoğlu, M. (1983). Din sosyolojisi. Ankara: Ankara Üniversitesi İlahiyat Fakültesi. 
Yel, M., Öztaş, F., \& Öztaş, H. (2005). Biyoloji eğitiminin diğer canlılar ve çevreye karşı insan etik değerlerinin oluşumu üzerin etkileri. Gazi Üniversitesi Gazi Eğitim Fakültesi Dergisi, 25(3), 295-306.

Yılar, Ö. (2005). Mit- efsane ve eğitim. Kazım Karabekir Eğitim Fakültesi Dergisi, 11, 1-4.

Yıldırım, A., \& Şimşek, H. (2016). Sosyal bilimlerde nitel araştırma yöntemleri (5. Baskı). Ankara: Seçkin.

Yılmaz, M., \& Çimen, O. (2012). İlköğretim öğrencilerinin geri dönüşümle ilgili bilgileri ve geri dönüşüm davranışları. Uludă̆ Üniversitesi Eğitim Fakültesi Dergisi, 25(1), 63-74.

Yılmaz, M., \& Çimen, O. (2014). Dönüşümsel öğrenme kuramına dayalı çevre eğitiminin biyoloji öğretmen adaylarının çevre sorunlarına yönelik algısına etkisi. Bartın Üniversitesi Eğitim Fakültesi Dergisi, 3(1), 339-359.

Etik Kurul Kararı: Bu çalışma 2019 yılında tamamlanan bir yüksek lisans tezinden üretilen çalışma olduğundan etik kurul kararı şartı gerekmemektedir. 